\title{
A preliminary survey of birds from the Lac Lobeke Reserve, south-eastern Cameroon
}

\author{
THOMAS B. SMITH, KAREN K. RASMUSSEN, KENNETH D. WHITNEY \\ and MARK K. FOGIEL
}

\section{Summary}

The rainforest avifauna of south-eastern Cameroon is poorly known. In one of the first surveys of birds from this region, we report on bird species netted and observed in the Lac Lobeke Reserve. We document 11 minor range extensions, including that of the extremely rare Zenker's Honeyguide Melignomon zenkeri. The abundance of several rare species of birds and mammals in the area, in addition to low human densities and relative inaccessibility, should make the Lac Lobeke region a priority in conservation efforts. Currently, large logging operations and the commercial exploitation of wildlife threaten the fauna of the region.

\section{Introduction}

While the biota of rainforests of south-eastern Cameroon have been little studied, recent faunal surveys suggest that they are particularly species-rich (Stromayer and Ekobo 1991). These forests, along with adjoining forests in the Central African Republic (CAR), may contain some of Africa's largest intact populations of elephant Loxodonta africana, bongo Tragelaphus euryceros and lowland gorilla Gorilla gorilla (Stromayer and Ekobo 1991). Although there are two published surveys of the avifauna in CAR from the Dzanga-Sangha Forest Reserve and National Park (Carroll 1988, Green and Carroll 1991), there is no published information on the avifauna of the neighbouring Lac Lobeke region of Cameroon.

Designated as a faunal reserve (IUCN 1987), the Lac Lobeke Reserve (Figure 1 ) is currently being considered as a component of a tri-national conservation plan which would link it with Dzanga-Sangha Forest Reserve and National Park in CAR and Nouabalé-Ndoki National Park in Congo (Carroll and Weber 1991). The vegetation of the region is characterized by small herbaceous marshes (Figure 2) within blocks of continuous forest (Letouzey 1986). The region has an equatorial climate with an average annual temperature of $25^{\circ} \mathrm{C}$ and a yearly precipitation of approximately 1,600 $\mathrm{mm}$, with two wet and two dry seasons (Etia 1980).

Currently, human disturbance at the core of this site remains negligible with densities less than one person per square kilometre (Hall 1993). However, pressures from both logging and commercial bushmeat harvesting appear to be increasing. Approximately $85 \%$ of the areas surrounding Lac Lobeke are under logging concessions (Gartlan 1988), and three logging operations are active. A 


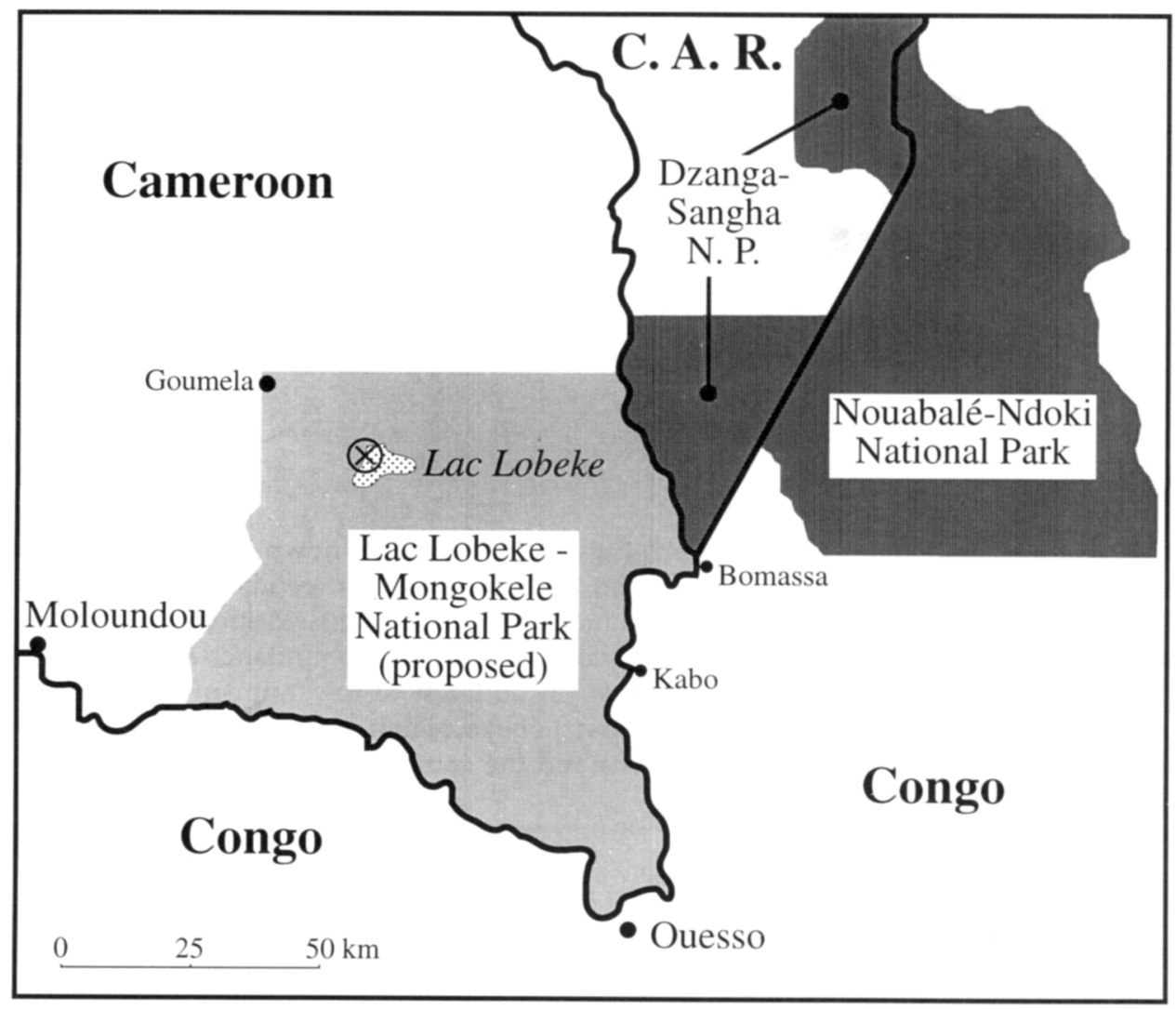

Figure 1. Location of the study site (crossed circle) and the Lac Lobeke region. Boundaries of the proposed Lac Lobeke-Mongokele National Park follow Curran (1993).

well-maintained network of roads allows for ready transport of harvested animals by logging truck. In addition, the Ngoko and Sangha rivers are being utilized to transport bushmeat to markets (Curran 1993). Capture of African Grey Parrots Psittacus erithacus for foreign export has also been taking place sporadically within the boundaries of the reserve since at least 1991.

\section{Methods}

Fieldwork was conducted in the northern portion of the proposed Lac Lobeke-Mongokele National Park $\left(2^{\circ} 18^{\prime} 39^{\prime} \mathrm{N} 15^{\circ} 45^{\prime} 42^{\prime} \mathrm{E}\right.$; see Figure 1) from 2529 June 1992, during the minor dry season. We sampled two sites, one in forest bordering a marsh and the other in forest $>500 \mathrm{~m}$ from the marsh. We used surveys and mist-netting to estimate species richness and abundance, respectively. Surveys were conducted by slowly walking through the forest or forest/marsh edge while recording all birds seen and heard. Mist-netting was conducted over three consecutive days in the forest and at the forest/ swamp-savanna edge. A total of 30 mist-nets (each $12 \mathrm{~m}$ in length, with mesh $30 \times 30 \mathrm{~mm}$ ) were erected along lines cut in the forest or along existing elephant 


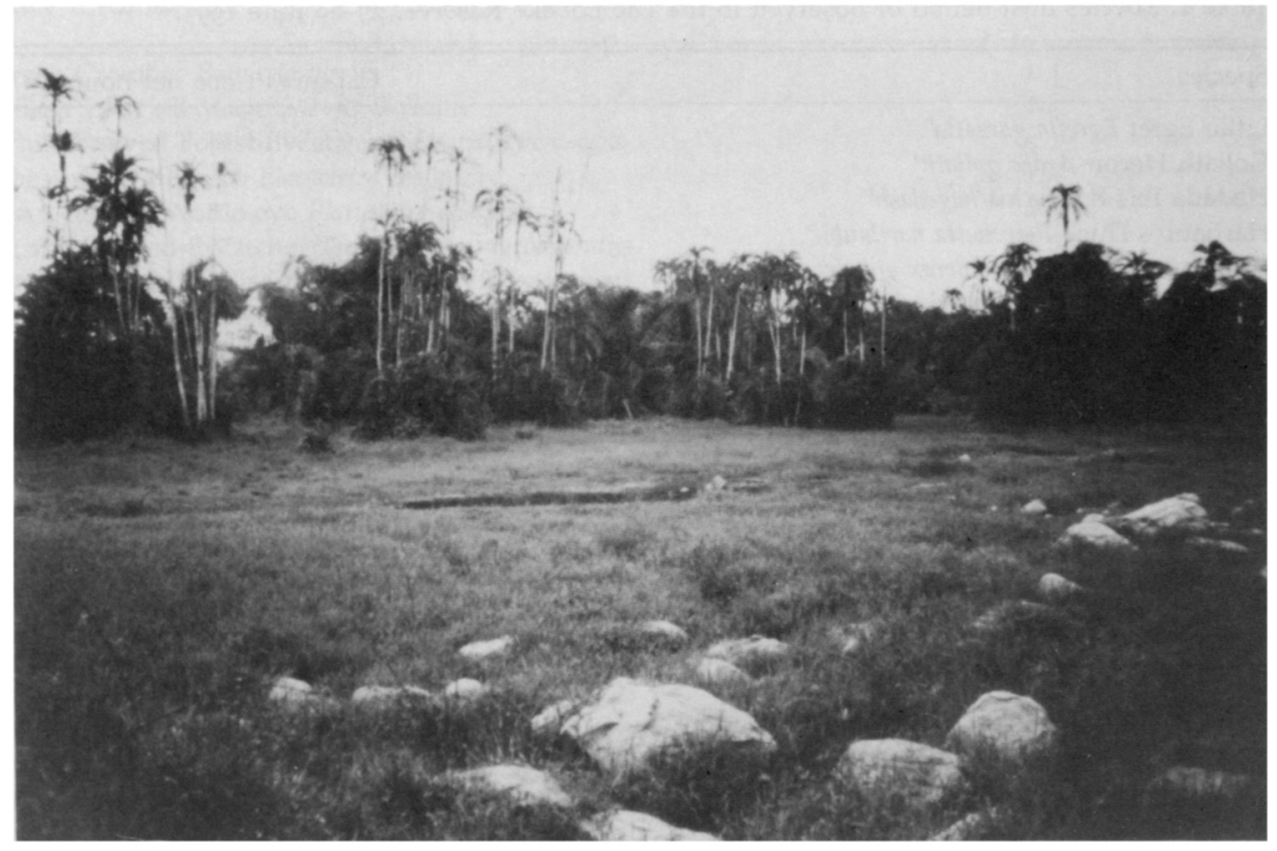

Figure 2. Herbaceous marsh characteristic of the Lac Lobeke Reserve. Surveys were conducted in the marsh and forest, while mist-netting took place in the forest adjacent to the marsh. Photograph by T. B. Smith.

trails. Nets were opened at sunrise (o6hoo) and closed at sunset (17h3o) or during rains. A total of 696.7 net-hours were logged. Captured individuals were banded, weighed and measured (see Smith 1990), and blood and feather samples were collected for molecular genetic studies. For each species, the number of individuals caught per 1,000 net-hours was calculated. Species observed both in mist-nets and in surveys are recorded here as mist-netted only. Range extensions are evaluated using maps given in Fry et al. (1988) and Keith et al. (1992).

\section{Results and discussion}

A list of the species from the mist-net and survey data is given in Table 1 . Species caught with the highest frequencies included: Indicator maculatus, Alcedo leucogaster, Alethe diademata, Andropadus virens, Andropadus latirostris, Bleda syndactyla, Bleda eximia, Malacocincla cleaveri and Nectarinia olivacea (Table 1).

Three species which were particularly common at the site were the Grosbeak Weaver Amblyospiza albifrons, observed in a nesting colony bordering the forest and containing more than 30 nests, the Hadada Ibis Bostrychia hagedash, observed in flocks of up to 40 individuals during the evenings, and the African Green-pigeon Treron australis, observed in flocks numbering several hundred individuals.

An unexpected and extremely rare bird netted in this brief survey was a Zenker's Honeyguide Melignomon zenkeri. Few records of this species are known 
Table 1. Species mist-netted or observed in the Lac Lobeke Reserve, 25-29 June 1993.

\begin{tabular}{|c|c|}
\hline Species & Captures/1,ooo net hours \\
\hline Little Egret Egretta garzetta $a^{\mathrm{b}}$ & - \\
\hline Goliath Heron Arden golinth & - \\
\hline Hedada Ibis Bostrychia hagedash ${ }^{\mathrm{h}}$ & - \\
\hline Hartlaub's Duck Pteronetta hartlanbil & - \\
\hline Palm-nut Vulture Gypohierax angolensis ${ }^{\mathrm{h}}$ & - \\
\hline Chestnut-flanked Goshawk Accipiter castanilitis & 1.4 \\
\hline African Fish-eagle Halinetus aocifer & - \\
\hline Peregrine Falcon Falco peregrinus & - \\
\hline African Jacana Actophilomis africanuts ${ }^{h}$ & - \\
\hline Red-eyed Dove Streptopelia semitorquatab & - \\
\hline Blue-headed Wood-dove Turtur brehmeri & 2.9 \\
\hline African Green-pigeon Treron australis & - \\
\hline Grey Parrot Psittacus erithacus ${ }^{\mathrm{h}}$ & - \\
\hline Great Blue Turaco Corythaeola cristata & - \\
\hline Red-chested Cuckoo Cuculus solitarius & 2.9 \\
\hline Sabine's Spine-tail Chaetura sabini ${ }^{\text {b }}$ & - \\
\hline White-bellied Kingfisher Alcedo lencogaster & 11.5 \\
\hline Woodland Kingfisher Halcyon senegalensis & 1.4 \\
\hline Blue-breasted Kingfisher Halcyon malimbica & 10.0 \\
\hline Chocolate-backed Kingfisher Halcyon badia & 2.9 \\
\hline Black Bee-eater Merops gularis ${ }^{2}$ & - \\
\hline Black-casqued Wattled Hornbill Ceratogymma atrata ${ }^{h}$ & - \\
\hline Brown-cheeked Hornbill Bycanistes cylindricus ${ }^{\mathrm{b}}$ & - \\
\hline Black-and-white Casqued Hornbill Bycanistes subcyindricust & - \\
\hline Hairy-breasted Barbet Lybitus hirsutus & 1.4 \\
\hline Lemon-rumped Tinkerbird Pogoniulus bilineatus & 1.4 \\
\hline Yellow-throated Tinkerbird Pogoniulus subsulphureus & 1.4 \\
\hline Red-rumped Tinkerbird Pogoniulus atroflatus & $1 \cdot 4$ \\
\hline Yellow-billed Barbet Trachyphonus purpuratus & 1.4 \\
\hline Spotted Honeyguide Indicator maculatus & $24 \cdot 4$ \\
\hline Least Honeyguide Indicator exilis & $5 \cdot 7$ \\
\hline Zenker's Honeyguide Melignomon zenkeri & 1.4 \\
\hline Brown-eared Woodpecker Campethera caroli & 1.4 \\
\hline Buff-spotted Woodpecker Campethera nizosa & I. 4 \\
\hline Plain Greenbul Andropadtis curirostris & $4 \cdot 3$ \\
\hline Little Greenbul Andropadus virens & 18.7 \\
\hline Yellow-whiskered Greenbul Andropadus latirostris & 53.1 \\
\hline Swamp-palm Bulbul Thescelocichla leucopleurus & 1.4 \\
\hline White-throated Greenbul Phyllastrephus albigularis & 7.2 \\
\hline Xavier's Greenbul Phyllastrephus xavieri & 1.4 \\
\hline Common Bristlebill Bleda syndactyla & 11.5 \\
\hline Green-tailed Bristlebill Bleda eximia & 30.1 \\
\hline White-bearded Greenbul Criniger calurus & 1.4 \\
\hline Fire-crested Alethe Alethe diademata & $14 \cdot 4$ \\
\hline Lowland Akalat Sheppardia cyornithopsis & $4 \cdot 3$ \\
\hline Forest Robin Stiphromis erythrothomax & 8.6 \\
\hline Blue-shouldered Robin-chat Cossypha cymocampter & 1.4 \\
\hline Red-tailed Ant-thrush Neocossuphus rufus & 2.9 \\
\hline White-tailed Ant-thrush Neocossyphtus poensis & $5 \cdot 7$ \\
\hline Rufous Flycatcher Stizorhina fraseri & 1.4 \\
\hline Brown Illadopsis Malacocincla fulescens & 5.7 \\
\hline Blackcap Illadopsis Malacocincla cleateri & 12.9 \\
\hline Green-backed Camaroptera Camaroptera chloronota & 2.9 \\
\hline Grey-backed Camaroptera Camaroptera brachyum & 1.4 \\
\hline
\end{tabular}


Table 1. (contd.)

\begin{tabular}{lr}
\hline Green Crombec Sylvietta zirens & 1.4 \\
Yellow Longbill Macrosphenus flavicans & 1.4 \\
White-browed Forest-flycatcher Fraseria cinerascens & $5 \cdot 7$ \\
Chestnut Wattle-eye Platysteira castanea & 1.4 \\
Black-necked Wattle-eye Platysteira chalybea & 2.9 \\
Dusky Crested-flycatcher Trochocercus nigromitratus & 8.6 \\
Black-headed Paradise-flycatcher Terpsiphone nitens & 1.4 \\
Red-bellied Paradise-flycatcher Terpsiphone rufiventer & 1.4 \\
African Paradise-flycatcher Terpsiphone viridis & 1.4 \\
Olive Sunbird Nectarinia olivacea & 27.3 \\
Black-bellied Seedcracker Pyrenestes ostrinus & 1.4 \\
Magpie Mannikin Lonchura fringilloides & - \\
Flower-pecker Weaver-finch Parmoptila woodhousei & - \\
Bluebill Spermophaga haematina & 2.9 \\
Grosbeak Weaver Amblyospiza albifrons & 10.0 \\
\hline
\end{tabular}

Species names follow Louette (1982).

a Observed once or rarely.

observed daily, common.

from Cameroon and few specimens exist in museum collections (Friedmann 1968, Colston 1981, Bowden et al. 1995). Intensive mist-netting conducted over a seven-year period (1983-1990) and consisting of over 16,000 individual captures along the Nyong river near Ndibi, Cameroon, resulted in only one capture (T.B.S. unpubl. data). The species is not yet recorded in CAR (Carroll 1988, Green and Carroll 1991). Measurements (mm) from the Ndibi and Lac Lobeke specimens, respectively, are: wing 73.8, 70.1; tail 51.9, 50.9; tarsus 12.8, 13.5; culmen 10.0, 9.3; weights (g) are 22.0, 20.0. These measurements are similar to those of Colston (1981) for $M$. zenkeri and the Yellow-footed Honeyguide $M$. eisentrauti. Given the scarcity of this species it is surprising that we caught an individual with such a limited trapping effort. Whether or not this reflects relatively higher densities of $M$. zenkeri at Lac Lobeke is unclear. Trapping success of honeyguides may have been increased during our study by the activities of local Baka hunters, who felled a nearby tree containing a hymenoptera nest to obtain honey.

In addition to Zenker's Honeyguide, the survey resulted in minor range extensions for to bird species. These species, and notes on their distribution and ecology, are given below.

Yellow-throated Tinkerbird Pogoniulus subsulphureus is a locally common resident of the forest in Cameroon, but has not previously been recorded from the south-east (Fry et al. 1988). It has been noted in adjacent regions of CAR (Carroll 1988). It primarily inhabits small clearings and secondary growth (T.B.S. unpubl. data).

Spotted Honeyguide Indicator maculatus has been found near Dimako in southern Cameroon (Fry et al. 1988) and in neighbouring CAR (Carroll 1988). It is an endemic resident of clearings in lowland and gallery forest and dense bush. It feeds on beeswax, arthropods and some small seeds (Friedmann 1955).

Lowland Akalat Sheppardia cyornithopsis has been recorded in south-western but not previously in south-eastern Cameroon (Keith et al. 1992), nor is it known from neighbouring CAR (Carroll 1988, Green and Carroll 1991). It is a common 
or locally abundant endemic resident of lowlands, found in the undergrowth of primary and secondary forest, forest-grassland mosaic and seasonal swamp-forest (Prigogine 1984, T.B.S. unpubl. data).

Plain Greenbul Andropadus curvirostris has been recorded in south-western CAR (Carroll 1988) and in south-western Cameroon (Keith et al. 1992), but not previously from south-eastern Cameroon. It inhabits primary, secondary and gallery forests and often forages in mixed-species flocks (Brosset and Erard 1986, T.B.S. unpubl. data).

Yellow-whiskered Greenbul Andropadus latirostris remains unrecorded in CAR (Carroll 1988, Green and Carroll 1991), and has only otherwise been observed in western and southern Cameroon (Keith et al. 1992). It inhabits both primary and secondary forests, may undergo local seasonal migrations (T.B.S. unpubl. data), and has a broad diet consisting of fruits, molluscs, insects and arachnids (Keith et al. 1992).

Swamp-palm Bulbul Thescelocichla leucopleurus is found in southern Cameroon and neighbouring CAR (Carroll 1988, Green and Carroll 1991). It is a common resident of swampy areas containing palms and is often found in groups of 35 individuals (Brosset and Erard 1986, T.B.S. unpubl. data).

White-throated Bulbul Phyllastrephus albigularis is a resident species of western and south-western Cameroon. It has been recorded in CAR (Carroll 1988, Keith et al. 1992). An inhabitant of both primary and secondary forest, it often joins mixed-species flocks (Brosset and Erard 1986, T.B.S. unpubl. data).

Xavier's Greenbul Phyllastrephus xavieri has been recorded in south-western CAR (Carroll 1988, Green and Carroll 1991), but has not previously been recorded in south-eastern Cameroon.

Forest Robin Stiphrornis erythrothorax has been found in neighbouring CAR (Carroll 1988) and in much of southern Cameroon (Keith et al. 1992). An inhabitant of lowland dense thickets, rainforest, riverine and transitional montane forest, it commonly follows ant columns (Brosset and Erard 1986).

Dusky Crested-flycatcher Trochocercus nigromitratus is commonly found in the coastal forests of Cameroon, near the town of Dimako to the east (Louette 1982), and in neighbouring CAR (Carroll 1988, Green and Carroll 1991). A shy species found in the lower undergrowth, it occasionally joins mixed-species foraging flocks (Mackworth-Praed and Grant 1973).

\section{Conservation}

The present study, though too brief to be conclusive, suggests that the Lac Lobeke region has the potential to be as important a site for rare birds as it is for rare mammals. Given its importance for wildlife, its current low human population density and its limited accessibility from major urban areas, the Lac Lobeke region should be of high priority in conservation efforts. As logging and poaching increase, it is likely that the value of the region will diminish rapidly.

A particularly serious threat is posed by the trapping of African Grey Parrots for commercial export. During our brief survey we observed the removal of over 300 parrots from the Lac Lobeke Reserve. This level of exploitation was still in effect in July 1995 (M. Kimura pers. comm.). With the creation of new 
roads for logging, it is likely that impacts on parrot populations will intensify. Data collected over the last 10 years near Akonolinga, Cameroon suggest that African Grey Parrot numbers in many areas of the country are decreasing (T.B.S. unpubl. data). Given the species's low reproductive rate, colonial roosting behaviour and high commercial value, these apparent population declines are a matter of concern.

\section{Acknowledgements}

We wish to thank the Government of the Republic of Cameroon for permission to conduct the research. The work was supported by grants from NERC, U.K. and NYZS/The Wildlife Conservation Society, U.S.A.

\section{References}

Bowden, C. G. R., Hayman, P. V., Martins, R. P., Robertson, P. A., Mudd, S. H. and Woodcock, M. W. (1995) The Melignomon honeyguides: a review of recent range extensions and some remarks on their identification, with a description of the song of Zenker's Honeyguide. Bull. Afr. Bird Club 2: 32-38.

Brosset, A. and Erard, C. (1986) Les oiseaux des régions forestières du nord-est du Gabon, 1. Paris: Société Nationale de Protection de la Nature.

Carroll, R. W. (1988) Birds of the Central African Republic. Malimbus 10: 177-200.

Carroll, R. W. and Weber, W. (1991) An integrated plan for regional forest conservation and management in southeastern Cameroon, southwestern Central African Republic and Northern Congo. Report to U.S. Agency for International Development.

Colston, P. R. (1981) A newly described species of Melignomon (Indicatoridae) from Liberia, West Africa. Bull. Brit. Orn. Club 101: 289-291.

Curran, B. (1993) Preliminary assessment of issues affecting the human populations of the Lac Lobeke region, southeastern Cameroon. Report for the Wildlife Conservation Society and the World Bank.

Etia, P. M. (1980) Climate. Pp.16-19 in G. Laclavere, ed. Atlas of Cameroon. Paris: Jeune Afrique.

Friedmann, H. (1955) The honey-guides. Bull. U.S. Natn. Mus. 208.

Friedmann, H. (1968) Zenker's Honey-Guide. J. Orn. 109: 276-283.

Fry, C. H., Keith, S. and Urban, E. K. (1988) The birds of Africa, 3. London: Academic Press.

Gartlan, S. (1989) La conservation des ecosystèmes forestiers du Cameroun. Gland, Switzerland: IUCN.

Green, A. A. and Carroll, R. W. (1991) The avifauna of Dzanga-Ndoki National Park and Dzanga-Sangha Rainforest Reserve, Central African Republic. Malimbus 13: 49-66.

Hall, J. (1993) Report on the strategic planning mission for the creation of a protected area in the Lobeke region of southeastern Cameroon: assessment of timber exploitation, safari hunting, and preliminary vegetation analysis. Report to the Wildlife Conservation Society.

IUCN (1987) IUCN directory of Afrotropical protected areas. Cambridge, U.K.: IUCN Conservation Monitoring Centre and IUCN Commission on National Parks and Protected Areas.

Keith, S., Urban, E. K. and Fry, C. H. (1992) The birds of Africa, 4. London: Academic Press. 
Letouzey, R. (1986) Étude phytogéographique du Cameroon. Encyclopédie Biologie 69. Louette, M. (1982) The birds of Cameroon: an annotated checklist. Brussels: Verhandeling Wetenschappen 43 (163).

Mackworth-Praed, C. W. and Grant, C. H. B. (1973) African handbook of birds, 2. New York: Longman.

Prigogine, A. (1984) L'Alethe à poitrine brune, Alethe poliocephala, au Rwanda et au Burundi. Gerfaut 74: 181-184.

Smith, T. B. (1990) Patterns of morphological and geographic variation in trophic bill morphs of the African finch Pyrenestes. Biol. J. Linn. Soc. 41: 381-414.

Stromayer, K. A. and Ekobo, A. (1991) Biological surveys of southeastern Cameroon. Report to the Wildlife Conservation Society.

THOMAS B. SMITH, KAREN K. RASMUSSEN, KENNETH D. WHITNEY and MARK K. FOGIEL

Department of Biology, San Francisco State University, 1600 Holloway Avenue, San Francisco, CA 94132 , U.S.A. 